期日：昭和51年 6 月 11 日

会場 : 新渴県民会館

\title{
パネルディスカッション：慢性肝疾患のステロイド療法
}

司会：市田 文弘（新潟大学第三内科）

\section{1. 肝におけるクルココルチコイドの代謝}

\author{
河 野 剛 \\ （京都大学第二内科）
}

ヒトの副腎皮質から分必される steroid hormone は主 として肝に执いて酵素的不活性化を5けて代謝され，主 として库中に非泄される。この代謝に関与する主要な醉 素は, hydrogenase(reductase), hydroxysteroid dehydrogenase, hydroxylase および glucuronyl transferase である. 天然の glucocorticoid である cortisol の代謝に際して は, cortisol のみに特異的な $\Delta^{4}-5 \beta$-ないし $\Delta^{4}$-5 $\alpha$-hydrogenaseのはたらき以外に，比較的特異性の少ない11 $\beta$ - お $よ ひ ゙ 3 \beta$-hydroxysteroid dehydrogenase, glucuronyl transferase のはたらきにより，主として易水溶性の結合型代 謝産物に転換する。一方，非天然型の合成glucocorticoid
たとえば prednisolone や betamethasone の代謝に際し ては、これに特異的な hydrogenase が肝に存在しないの で，比較的特異性の少ない醳素系によって代謝産物に転 換する，したがって，cortisolの場合に比べて一般に代謝 が途れ，尿中には遊離型分画が比較的多く，結合型分画 は比較的少ない。亩た, 代謝産物への軽換形式。 cortisol の”場合とかなり異なる. 著者らが $5 \mathrm{mg} の{ }^{3} \mathrm{H}$-fluo-

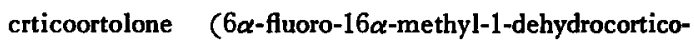
sterone）の経口投与後の代謝を正常人 3 例でしらべた結 果です "), 総放射能の泄排は48時間で約50〜60\% (Fig. 1) と, cortisol $989 \% \%^{2)}$ に比べて低く, 遊離型代謝産

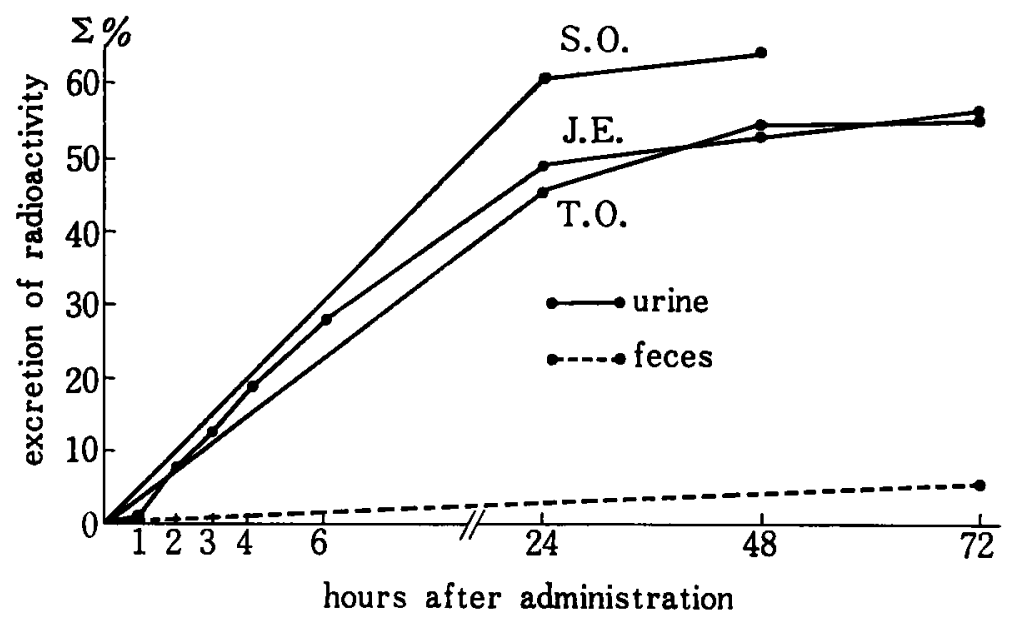

Fig. 1. Per cent excretion of radioactivity in urine and feces after oral administration of ${ }^{3} \mathrm{H}$-fluocortolone to normal subjects 


$\begin{array}{cccc}F_{1} & F_{2} & F_{3} & F_{4} \\ (29 \%) & (14 \%) & (23 \%) & (12 \%) \\ \text { Rf } 0.15 & \text { Rf } 0.31 & \text { Rf } 0.38 & \text { Rf } 0.51\end{array}$

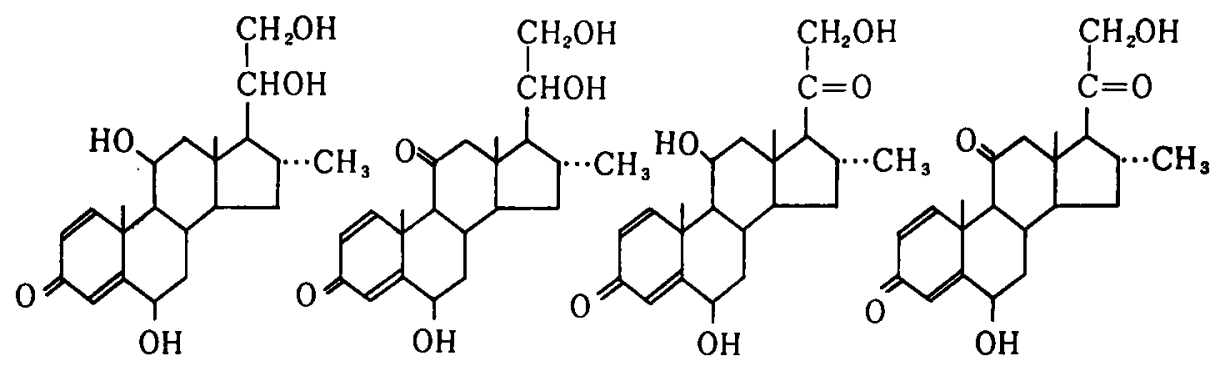

Fig. 2. Suspected metabolites of fluocortolone in urinary free fraction

$\mathrm{G}_{2}$

(19\%)

Rf 0.22
$\mathrm{G}_{5}$

$(27 \%)$

0.48
$\mathrm{G}_{6}$

$(20 \%)$

Rf 0.60

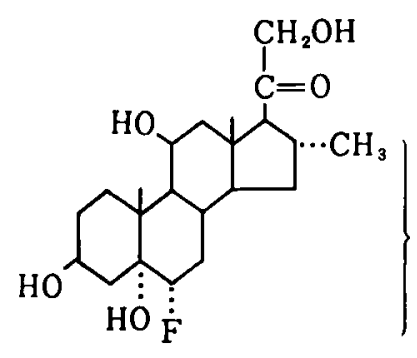

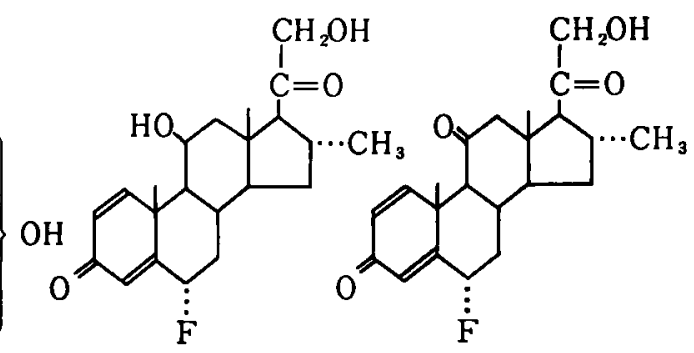

Fig. 3. Suspected metabolites of fluocortolone in urinary glucuronide fraction

物の中では, $6 \alpha$-fluoro 型から転して $6 \beta$-hydroxyl 型に, 一部ではさらに 11-dehydro 型になったものが主体とな っており(Fig. 2 ), glucuronide の中では, fluocortolone 21-glucuronide, 11-dehydrofluocortolone 21-glucuronide, tetrahydrofluocortolone のさらにもら1カ所 hydroxylationをらけたものの glucuronide などが主体となってい る (Fig. 3 ).

幵硬変や急性肝炎においては，肝細胞の重篤な障害な いし肝の有効循環血液量の減少のため, glucocorticoid の代謝は遅延する．放射性 cortisol を静注してしらべ るど, cortisol の metabolic clearance rate は低值と なり，怙そらくこの代謝集延による cortisol の血浆濃度 上昇に対する negative feedback により ACTH 分泌減 少を介して cortisol の 1 日分泌量は大多数の例で低值を
示した。これによって血浆濃度を正常に近づけようとす る機構と思われるが， cortisol の1 日平均血浆濃度を実 際に測定して見ると，肝硬变では不定の值を，急性肝炎 では高値を示した。これは, 代謝の遅延と分泌の減少と がうまくつり合わない症例があるためと考えられる．慢 性肝炎の 5 例では 1 日分泌量が低值で，その中 1 例では metabolic clearance rate が高値で, 血浆濃度は低値を 示したが，その理由は不明である。また，放射性 cortisol 静注後の24時間尿中の放射性分画では ${ }^{3)}$, 肝硬変と急 性肝炎において遊離型分画の增加が，肝硬变において glucuronide 分画の減少が見られこれら重篤な肝疾患 では cortisol の酵素的不活性化が障害されていることを 示したが, 慢性肝炎の1例では,これら雨分画は正常 値を示した。 また glucuronide 分画中の主要代謝産物 
の pattern paper chromatography にて分析すると, tetrahydrocortisol/allotetrahydrocortisol + tetrahydrocortisol 比が肝硬変において減少傾向を示したので，本症で は $11 \beta$-hydroxysteroid dehydrogenase による cortisol か 5 cortisonen への転换が障害されている可能性がある. 一方, allotetrahydrocortisol/tetrahydrocortisol比は肝硬変 と慢性肝炎では正常人のそれと有意差なく，急性肝炎の 1 例でも正常値を示した. 肝硬変や急性肝炎では cortisol の $\Delta^{4}$-hydrogenation の低下が主体となって主要代謝産 物の glucuronide 生成量が減少すると考古られている が, 以上の成績から，その際 $\Delta^{4}-5 \alpha$-hydrogenation の低 下度と $\Delta^{4}-5 \beta$-hydrogenation の低下度とが同程度である と思われる。

肝硬变では cortisol の血粼蛋白結合能が低値を示する のが一部に見られた。しかし，実際に血浆中のtranscortin 濃度と cortisol 濃度とを測定して見ると，本症 7 例中 一部の症例では正常值よりる低いるのもあったが，全体 としては正常人との間に有意差はなかった．肝硬変では albuminの合成が低下するが， transcortin は $\alpha_{1}$-globulin 分画に含まれるので，本症で著明な減少が一般に見ら れないものと考えられる，一方，ルポイド肝炎を含む慢 性肝炎 5 例では，血粼 cortisol 濃度が正常人との間に有
意差を示さなかったにるかかわらず血根 transcortin 清度 が高值を示したが，その理由は不明である。

合成 glucocorticoid の肝疾患における代謝をしらべた 報告はあまり見られないが，著者らは正常人と門脈大静 脈吻合術を施行した肝硬変患者に "C-paramethasone を 経口投与し，患者では24時間尿中の遊雄型分画中への ${ }^{14} \mathrm{C}$ の排泄が正常人より多く，glucuronide 分画中への ${ }^{14} \mathrm{C}$ の排泄が正常人よりも少ないという成績を得，合成 glucocorticoid の代謝にす肝が重要なことを知った。

索引用語 : glucocorticoid 代謝, fluocortolone, paramethasone

文献

1) 河野 剛, 吉見輝也, 遠藤治郎 : ${ }^{8} \mathbf{H}$-fluocortolone $の$ 代謝に関する臨床的研究. 内科宝函, $20: 129,1973$.

2) Cope, C.L. and Black, E.: The production rate of cortisol. Brit. M. J., 1: 1020, 1958.

3) Kono, T., Yoshimi, T. and Miyake, T.: Metabolic clearance of aldosterone, cortisol and corticosterone in various clinical conditions. Steroid Dynamics, p. 429, 1966. Academic Press, Inc., New York.

\title{
2. 副腎皮質ホルモンの抗炎症作用とその副作用
}

\author{
矢 野 三 郎 \\ (富山医科薬科大学内科)
}

1948年, Hench が慢性関節リウマチの 1 例にコーチ ソンを使用して劇的な効果を認めて以来，ステロイド斉 は各種疾患に広く応用されるに至った。しかし一方では 重篤な副作用のあることが明らかになり，本剤に対して 批判的な傾向る強くなっている.ところが最近，ステロ イドの作用機序に関する研究が画期的な進歩をとげ，臨 床的にむ投与方法の改善など副作用の軽減にむかっての 研究が積重ねられてきた結果，ステロイド療法に再び明 るい希望があてるよらになってきた. 本稿ではステロ1 ドの作用機序に関する最近の知見を紹介するとともに， 現状において最善と考えられる副作用防止対策について 述べ，慢性肝疾患におけるステロイド療法の参考に供し たいと思う。

\section{1）ステロイドホルモンの作用機序}

Tomkins らによってグルココルチュイドの細胞内レセ プターの存在が明らかにされ，多くの作用が分子レベル で解明されつつある。しかし臨床的に重要な抗资症作用 に関しては詳細な研究に乏しい。グルココルチュイドは 炎症の全過程に影響を与えることが知られているが，と くに細小血管壁に対する作用，炎症巣への白血球集積の 抑制, 線維芽細胞の增殖抑制などが主要な作用である. フレルギー性炎症に括いては第3 型（アルサス型）およ び第 4 型 (ツベルクリン型) に対する影諳が顕著であ $\eta$, 第 3 型では抗原一抗体結合物の組織への沈着抑制, 血管透過性穴進の抑制，炎症巣への白血球集積の抑制な どが認められ，第 4 型ではマッロファージのの遊走抑 
制, lymphokines (MIF など) の作用阻止などが認めら れる。

つぎにグルココルチコイドの作用として兔疫抑制があ る. 近年, 免疫学自体の進歩が急速であり, ステロイド の影響に関する研究はこれに追いつくことができない現 状である.リンパ組織のステロイドに対する感受性は種 属によって相違があり, hamster, mouse, rat, rabbit は sensitive, ferret, monkey, guinea pig, man は resistant $と$ されている.また，同じ種属であっても T-cell とB-cell によって異なるし，さらにそれぞれの cell line であ成 熟段階によって感受性を異にする。一般的に言えば成熟 細胞より未熟な細胞がステロイドに sensitive であり， 活性化されたリンバ球に関しては T B B resistant で ある。また，T-cell による effector mechanism はステ ロイドに sensitive であるが, B-cell の抗体産生は resistant であるとみなされている，ヒトのリンパ球に対す るステロイドの影響に関する研究が進展を示したのはこ の $2 \sim 3$ 年内のことである. ステロイドを投与すると血 中リンパ球数が著明に減少，4時間で最低に達するが， 24時間後に旧値に回復する。この場合，T-cell は B-cell に比して減少が著明であり，また血中に残存しているリ ソバ球の機能を幼若化現象によって検討すると，ステロ イド投与 4 時間後では低下が認められている.また単球 ーマクロファージェ采に対する影響では，ステロイド投 与 4 時間後, リンハ球と同様, 血中単球の減少が認めら れ，この他ステロイドによって抗原のマクロファージュ への取込み阻害, 単球の chemotaxis および殺菌作用の 阻害の接こることが明らかにされている. Claman らに よって人のリンハ球はステロイド resistant とされてい るが，細胞溶解はおこらなくてもリンパ球の動態に対し て顕著な影㸷を及ぼしている点に留意すべきである。

2) 㫜作用防止対策

副作用を防止するために以前から各種の葲剤を併用す るなど補助的な対策が試みられているが，いずれる满足 すべき結果を得ていない.これに反し，現在の所では hort acting steroid (prednisoloneなど)を用いる隔日 1
回投与法が副作用の発現を少なくする最善の方法となっ ている．本法はすでに1960年頃から提唱されていたが， 三投四休法に対する批判の影響むあったのか広く採用さ れるに至らなかった。しかしっここ数年,本法に関する基 礎的臨床的研究が格段の進歩を示し,ステロイド療法を 行ならに当ってはまず本法を試みることが奖められてい る任どである．私どすは SLE, RA, ITP, Behçet, colitis ulc. sarcoidosis などの症例に本法を試みた結果，連日投 与法に少らぬ臨床効果を認め，かつ副作用がほとんど発 現しないといち事実を確認した。すなわち, prednisolone 隔日 1 回60mg を初回量として数カ月治療を行っても副 腎不全を招来せず，またmoon face む発現しなかった。 Dale らによると delayed hypersensitivity reaction の抑 制むおこらず，感染症の合併がきわめて少ないといわれ ているが，私どすがサルコイドージスの症例で検討した 結果では T-cell 機能が㧕制されないといら成績を得て いる.今後の問題としては, 肝疾患を含め適応应を明ら かにすること，さらに長期間にわたる副作用のチェック などが残っている.

索引用語 : クルココルチコイドの抗炎症作用, 免疫抑 制

\section{主要参考文献}

1) Claman, H.N.: Corticosteroids and lymphoid cells. New Eng. J. Med. 287: 388, 1972.

2) Fauci, A.S. and Dale, D.C.: The effect of in vivo hydrocortisone on subpopulations of human lymphocytes. J. Clin. Invest. 53: 240, 1974.

3) Claman, H.N.: How corticosteroids work. J. Allergy Clin. Immunol. 55: 145, 1975.

4) Baxter, J.D. and Harris, A.W.: Mechanism of glucocorticoid action: general features, with reference to steroid-mediated immunosuppression. Transplantation Proceedings 7: 55, 1975.

5) Axelrod, L.: Glucocorticoid therapy. Medicine 55:39, 1976. 


\title{
3. 慢性肝疾患のステロイド療法
}

\author{
山本祐夫 \\ （大阪市立大学第 3 内科）
}

\section{Prednisolone の免疫能に及ぼす影響}

活動性，進行性の慢性肝疾患のステロイド治療には prednisolone (pred) $20 \mathrm{mg}$ 前後を長期投与する方法が注 目されている.そこで，演者は先ず pred の免疫能に及 ぼす影響を検討した。

1) in vitroにおける prednisolone のリンパ球幼若化 反応に及ぼす影響： PHA-P, PWM, 及び PPD 刺激に よる末梢血りンパ球の奻若化反応が pred 添加により, どのような影響を受けるかを微量全血培養法を応用して 検討した. $\operatorname{pred} 1 \mu \mathrm{g} / \mathrm{m} l$ の添加により PHA 刺激による リンパ球幼若化反応は ${ }^{9} \mathrm{H}$-thymidine の取り込みメでみるる と，50\%以上抑制され，0.01 $\mathrm{g} / \mathrm{m} l$ の極めて低い濃度を 添加しても抑制効果は明らかであった，精製ツベルクリ ン PPD 刺激飞上る場合は， $1 \mu \mathrm{g} / \mathrm{m} l$ 以上添加して初め て明らかな抑制を示す。しか PWM 刺激に対しては pred の抑制効果は少なかった。

2）ステロイド治療と PHA 刺激リンパ球幼若化反 応：以下述ぺるステロイド治療の免疫能に及ぼす影響に 関する实験では，pred $20 \mathrm{mg}$ の連日投与群と隔日投与 群 (朝 $40 \mathrm{mg}$ 服用, 48時間後同量服用) 飞分け，投与前 及び投与開始60日後に諸種の検查を施行した。PHA 刺 激によるリンパ球ブラスト化を ${ }^{3} \mathrm{H}$-thymidine の取り远 みでみると，連日投与群では投与開始 2 週間後にいずれ も幼若化反応の抑制がみられ，その抑制は60日後には著 明であった。一方，隔日投与群では軽度の㧕制傾向がみ られるにすぎない。

3）ステロイド治療と「ツ」反応：連日投与群，隔日 投与群ともに，投与開始 2 カ月後にツベルクリン皮膚反 応方陰性転化した症例はみられなかった。

4）ステロイド治療と $T$ cell, B cell：沿療 2 カ月後 には pred 連日投与群では一定の傾向は認められない。 B cell 数は連日投与群で明らかな低下を示すが連日投与 群では変化は明らかでない。

5）ステロイド治療と HBs 抗体：HBs 抗体は RI 法 で測定した. HBs 抗体の力価の高い例は pred 連日投 与にて 2 週間後に明らかな力価の低下を示し，一方隔日 投与では軽度の力価の低下が認められるにすぎない。
6）ステロイド治療と HBs 抗原：HBs 抗原は RI 法 で測定した. HBs 抗原陽性例では 2 カ月の pred 治療中 に認さべき力洒の変動を示した例はなかった。

\section{II chronic active hepatitis の長期ステロイド治 裳成綂}

肝疾患ステロイド治療・大阪グループのメンパーであ る大阪大学, 大阪労災病院，大阪厚生年金病院，大阪府 立成人病センター，国立大阪病院，大阪府立病院，大阪 赤十字病院, 大阪市立大学の 8 施設から集計した臨床成 績を中間成績として今回発表する。

対象：慢性肝炎活動型23例，小葉改築傾向型12例, 合 計35例. 全例，治療前及び治療後に肝生検を施行して， 組織学的所見を対比した。

投与方法: 主として prednisolone $30 \mathrm{mg}$ より初め漸減 し，20mg，15mg, 10mg を維持量として長期投与した.

投与期間： 6 力月以下 6 例， 6 力月〜 1 年 11 例， 1 年 以上18例, 平均20カ月である。

1）肝機能に及代す影響：改善25例 $(71 \%)$,不変 7 例 (20\%), 悪化 3 例 $(9 \%)$. (図 1).

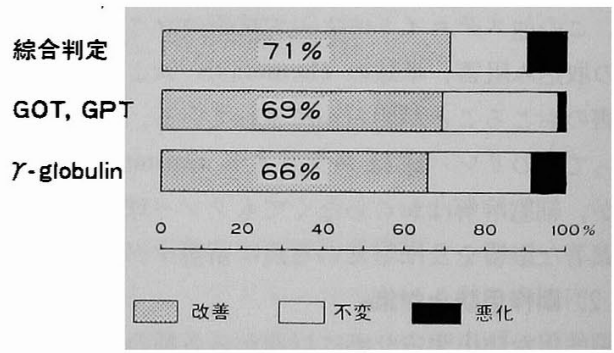

図 1 肝機能

2）肝組織像に及ぼす影響 : 改善21例 $(60 \%)$,不変10 例 $(29 \%)$, 悪化 4 例 $(11 \%)$.朋細胞変性壊死，星細胞反 応, グ鞘細胞浸潤，限界層の破絞に及ぼす影響は図 2 に 示す通りである。炎症所見の明らかな消退が半数以上の 症例にみられた．次に活動型（23例）と，小葉改築傾向 型 (12例) について, 肝組織像に及ぼす効果を比較飞 た. 活動型は改善14例 $(61 \%)$, 不変 7 性 (30\%), 悪化2 例 $(9 \%)$ であり，1 例のみが肝硬変に移行した. 改策 傾向型性改善 7 例 $(58 \%)$, 不変 2 例 $(17 \%)$, 覀化 3 例 


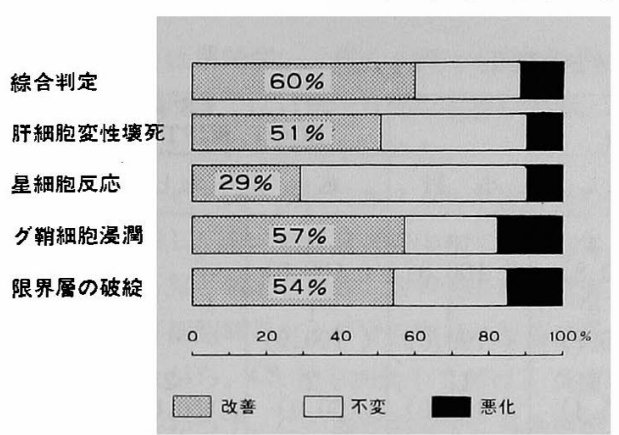

図 2 肝生檢儌

（25\%）で，5例が肝便変に移行した。すなおち，小葉 改築傾向型は 12 例中 5 例 (42\%), 慢性肝炎活動型は23例 中 1 例 $(4 \%)$ が肝硬変に移行した. しかし，肝硬変に 移行した 6 例中 3 例は炎症所見が消退しており，一般臨 床症状も良好で活動性が停止の状態にある。

3） HBs抗原とステロイド治療効果：ステロイド治療 例を血中 HBs 抗原陽性群13例と，陰性群22例に分けて 治療效果を比較した（表 1). HBs 陽性群では肝機能の 改善 $77 \%$, 悪化 $8 \%$ であり, 肝組織像では改善 $47 \%$,
表 1 HBs-Ag とステロイド治療好果

\begin{tabular}{|c|c|c|c|c|c|c|c|}
\hline \multirow{2}{*}{$\begin{array}{c}\text { 血 } \\
\mathrm{HB} \text { 中 } \\
\mathrm{HBg}\end{array}$} & \multirow[t]{2}{*}{ ' } & \multicolumn{3}{|c|}{ 肝機能 } & \multicolumn{3}{|c|}{ 肝生検像 } \\
\hline & & 改善 & 不変 & 息化 & 改善 & 不変 & 㯖化 \\
\hline \multirow{2}{*}{ 性 13例 } & 症例数 & 10 & 2 & 1 & 6 & 5 & 2 \\
\hline & $\%$ & 77 & 15 & 8 & 47 & 38 & 15 \\
\hline \multirow{2}{*}{ 陰 性 22例 } & 症例数 & 15 & 5 & 2 & 15 & 5 & 2 \\
\hline & $\%$ & 68 & 23 & 9 & 68 & 23 & 9 \\
\hline
\end{tabular}

覀化15\%であった。一方, HBs 陰性群では肝機能の改 善は68\%，悪化 $9 \%$ \%゙り，肝組織像では改善68\%，悪 化 $9 \%$ あった。一見, HBs 抗原陽性例は陰性例にく らべ, 肝組織像の改善が悪い上うに思点るが, 推計学的 に両群の治療効果には有意差はないままた，肝硬変へ移 行した 6 例中 4 例は HBs 抗原陽性であった。

4）副作用：moonface 14例, acne 14例，ステロイド 糖尿 5 例, 骨の变化 1 例, 胃・十二指腸溃瑒 1 例であっ た。

索引用語：ステロイド治療, 免疫能リンパ球纤若反応

\title{
4. 亜小葉性肝壊死を伴う慢性肝炎への 適応設定とその臨床成績
}

\author{
太畐 康 幸 \\ (愛媛大学医学部第 3 内科)
}

慢性肝疾患にたいするステロイド療法は，ルポイド肝 炎に代表される自己免疫性肝炎での有效性が認められ， その適応設定は慢性肝炎活動型にも拡大されて現在に至 っている. しかしその作用機序については未解波なとこ ろが多く，投与量や投与期間についてす異論があり，ま た十分な対象例についての controlled trial の成績を欠 く憾みがあった。しかるに近時, controlled trial に上 って，慢性肝疾患にたいするステロイド療法の有效性を

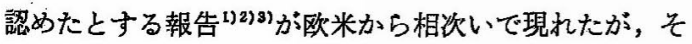
の投与対象例をみると，慢性肝炎のなかでも肝細胞壊死 がつよく肝硬変への移行傾向のつよい例，または肝硬変 例で，投与量は prednisolone (PS) 20〜15mg/日を初回 量とし,稚持量は可能な限り下げて，3 年ないし8 年に及 ‘゙長期投与での成績である，そこで，演者が:今回検討し た対象は，正小葉性肝燷死を伴う慢性肝炎としてその病
態を検索してきた慢性肝疾患であるが(5)，この適応設定 の理由は，1）遷延する肝炎のなかでも B 型肝炎ウィル ス感染症としての病態が明らかな例が多いこと，2）経 過中に亜小葉大の肝細胞壊死が綝り返し現われ，臨休 像のうえでは急性堌悪を繰り返し起こしてくること，3） 種々のいわゆる血中自己抗体を証明し, 血清 $\gamma$ グロプリ ンの異常高値を認めること，4）血中に HBAg-anti-HB immune complex 形成を認め, 血清トランスアミナーゼ 値の急嵕な上昇と関連して消長すること，5）肝硬変へ の移行率がきわめて高いことに基ついている.

投与対象：肝生検で診断された35症例で，すべて男性 である、B型肝炎ウイルス感染症としての観点に立ち, 血中 HBsAg の出現状況から I. 出没群，II. 常に陽 性群，III常に陰性群の 3 群に分けて検討した。投与法 は PS20mg を 1 日量として, SGOT, SGPT 活性値を指 
表 1 CS 投与とシューブとの関係

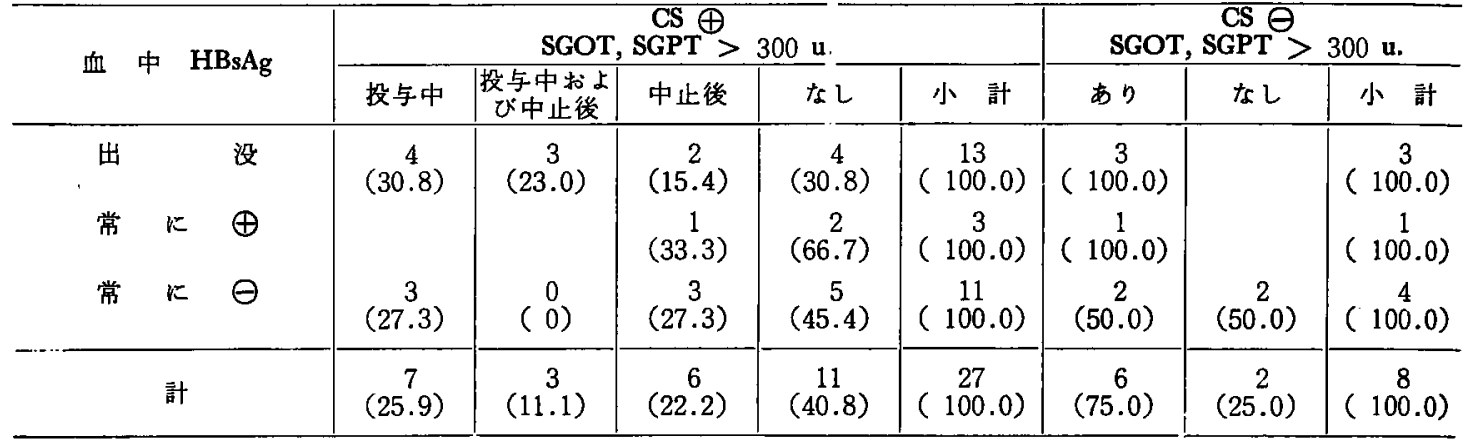

表 2 CS 投与例の血中 HBsAg の消長と急性增悪, 肝機能扰よび肝生検像との関係

\begin{tabular}{|c|c|c|c|c|c|c|c|c|c|}
\hline \multirow{2}{*}{ 群 } & \multirow{2}{*}{ 血中 HBsAg の消長 } & \multicolumn{2}{|c|}{ 急性增悪 } & \multicolumn{3}{|c|}{ 肝機能 } & \multicolumn{3}{|c|}{ 肝生桧像 } \\
\hline & & $\oplus$ & $\theta$ & 改善 & 不変 & 悪化 & 改善 & 不変 & 悪化 \\
\hline \multirow{3}{*}{ I } & 隇量中または中止直後に陰性化（5） & 3 & 2 & 5 & 0 & 0 & 5 & 0 & 0 \\
\hline & 中止後に陰性化 & 1 & 0 & 1 & 0 & 0 & 1 & 0 & 0 \\
\hline & ひきつづき出没 & 5 & 2 & 5 & 1 & 1 & 6 & 1 & 0 \\
\hline II & 常にゆ & 1 & 2 & 3 & 0 & 0 & 1 & 2 & 0 \\
\hline III & 常に $\theta$ & 6 & 5 & 9 & 0 & 2 & 8 & 1 & 1 \\
\hline
\end{tabular}

標として改善の徴がでるまで連日投与したのち，4 日投 与後 3 日休薬期をおく間歇投与法を採用した。な尔，免 疫学的背景において，3群間に差異があるかどらかを液 性拉よび細胞性免疫両面について検討したが，大差は見 出しえなかった，しかしながら，䀒組織内 HBsAg 沈着 量においては, I群，I群の順に多く，II群では肝組織 中に HBsAg を認めなかった。

成 第 1 群16例中13例に PS を 77〜1,095日（平 均 408日）間投与し，3 例を対照例とした。 PS 投与13 例中 5 例は PS減量中または中止後に血中HBsAg が陰性 化し (平均 12力月), 更に 1 例は投与中止後に陰性化し た. 牫る 7 例の血中 HBsAg はひきつづき出没した。一 方, 対照群 3 例中 1 例は陰性化し, 残る 2 例はひきつう き出没した，第II群 4 例中 3 例にPSを 167〜 444日 （平均 293日）にわたり投与した。投与した 3 例は肝機 能, 肝生検像で改善したが, 血中の HBsAg はひきつつ き陽性であり，いわゆるキャリフ状態として緩解をみ た。一方，非投与例は明らかに覀化した，第群15例中 11例に PSを 149～819日（平均 291日）間投与した。 らち2 例は投与中および投与後にそれぞれ anti-HBs

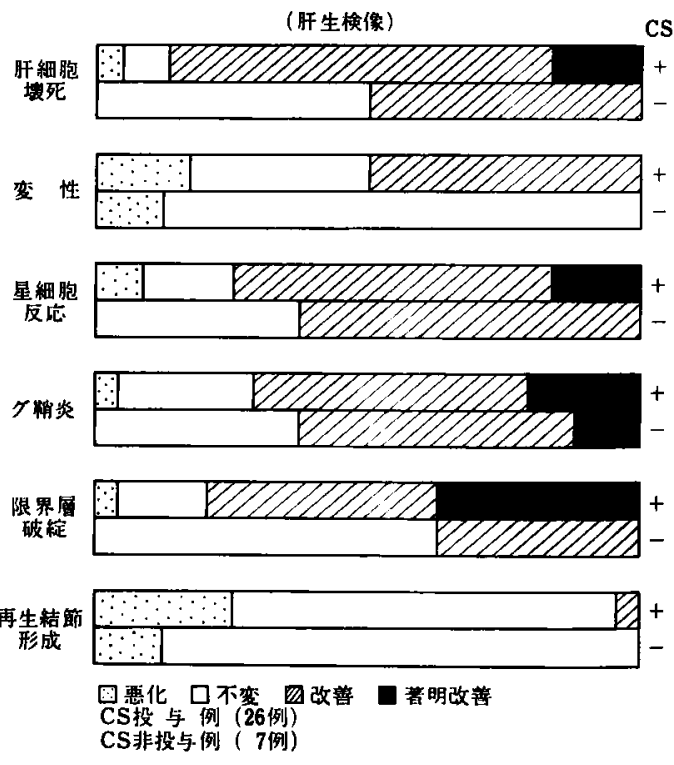

図 1 亜小葉性肝壊死を伴 5 慢性肝炎に対するCS 剂の効果 
を証明したことは興味深い，残る9例はすち論陰性で， 肝機能, 肝生検所見では11例中 9 例に改善を認め，対照 例よりも明らかに良好な経過を認めた。

図1はステロイド投与前後における肝生唡所見の変化 を対照群と比較したもので，総合的にみて改善81\%，不 変 $15 \%$, 悪化 4\%と判定された. 限界層破綻の改善, ク 靶资の減少，肝細胞㙘死および变性所見の改善が認めら れた。しかしながら，CS 投与26例中 7 例は，炎症所見 の改善にるかかからず，この観察期間中に再生結節形成 が起こり，肝硬変への移行を認めた事実は注目される。 表1はCS 投与によるシュープ発現の阻止効果をみたる ので，正群では CS 投与開始後に現れたシューブの頻度 は対照群と比較して減少していない。これに対してI群 とII群ではシューブが減少している傾向がらかがえた。 表 2 はステロイド療法での効果発現の機序を，血中 HBs Ag の消長との関連において検討したるので，I群では CS 投与後の肝生検所見の改善度がわるいが，I 群と III 群間では CS 投与による効果にとくに羑異を認めなかっ た.

耛 論：1．慢性肝疾患にたいするステロイド療法 は，亜小葉性肝堙死を繰り返して肝硬変への進展がつよ い上らな慢性肝资活動型に適応があり，少量を長期にわ たって投与すべきである．2．本療法での最も顕著な効
果は，肝生㭘所見における炎症所見の改善である． 3. HBsAg 陽性例飞る投与できる.4. CS 減量中または投 与中止直後に血中 HBsAg が陰性化する例があり，この 上らな例では予後が良い．5．肝機能および肝生検像が 改善されるにもかかわらず，血中 HBsAg は持続的注 明され，いかゆるキャリアとしての綏解，治窟例があ る. 6. 投与量からみて，その作用機序は免疫抑制とい らよりは抗炎症作用であり，免疫調整的な作用をむ想定 したい.

索引用語：ステロイド療法，亜小葉性肝壊死を伴う慢 性肝炎

\section{文 献}

1) Cook, C.G., Mulligan, R. and Sherlock, S.: Quart J. Med. 40: 159-185, 1971.

2) Soloway, R.D., Summerskill, W.H.J. et al.: Gastroenterology 63: 820-833, 1972.

3) Copenhagen study group for liver diseases: New Eng. J. Med. 291: 271, 1974.

4) 太田康幸, 过 孝夫, 小坂激夫：肝焱と $\mathrm{HB}$ 抗原，第 5 回犬山シンポジゥム記録. 1974, 53 頁.

5）太田康幸, 过 孝夫, 野㱦 筆: 臨床免疫, 7 : 1145-1155, 1975.

\title{
5. 慢性肝疾患のステロイド療法
}

\author{
稲 垣 威 彦
}

（新潟大学第 3 内科）

肝炎ウイルスの持続感染による慢性肝疾患に対する免 疫抑制療法としてのステイロド療法の目標を, ウイルス の persistent tolerant infection の状況に近づけることに あると設定し，かかる観点から本療法の効果と問題点を 検討した．即ちFig.1に示すような慢性肝疾患にお汀る 各種の免度学的パラメータの異常が， carrier state にお。 ける軽度の異常状態にまで近づき克るか否かを，その動 向を追って検索した。

\section{対象}

経時的に検索を行なった対象は10例で，HBs 抗原陽 性恃 7 例, HBs 抗体陽性は 3 例であった。組織学的誩 断は 5 例が慢性肝炎活動型で，一部では小葉改筑傾向を 伴っていた． 4 例は慢性の経過をとるが, 形態学的には

\begin{tabular}{|c|c|c|c|}
\hline & $\begin{array}{c}\text { HQV } \\
\text { CARRIER STATE }\end{array}$ & $\begin{array}{c}\text { CHRONIC LIVER } \\
\text { DISEASES }\end{array}$ & $\begin{array}{c}\text { IIMHUUO- } \\
\text { SUPPYESSTVE } \\
\text { THERAPY }\end{array}$ \\
\hline T-CELLS & $\searrow$ & $\downarrow$ & $\uparrow$ \\
\hline B-CELLS & $\lambda$ & $\uparrow$ & $\downarrow$ \\
\hline HBS Ag & $\uparrow$ & $\nearrow$ & $\uparrow$ \\
\hline IMMUNOGL OBUL INS & 7 & $\uparrow$ & $\downarrow$ \\
\hline COMPLEMENTS & $\searrow$ & $\downarrow$ & $\uparrow$ \\
\hline AUTOANTIBODIES & $\lambda$ & $\uparrow$ & $\downarrow$ \\
\hline MIF (HBs Ag) & $\downarrow$ & $\searrow$ & $\downarrow$ \\
\hline PHA IN VITRO & $\searrow$ & $\downarrow$ & $\uparrow$ \\
\hline
\end{tabular}

Fig. 1. Immunological abnormalities in chronic liver diseases 
ubacute hepatitis (Tidale) に該当した.1 例は活動型 の肝硬変であった。

\section{方 法}

ステロイドの使用方法は,プレドニソロン 1 日30mgを 4 日服楽, 3 日休薬して12週間継続し，直ちに休止した。 各種の免疫学的ハラメータの検索は，治㞠開始直前よ り 2 週間毎に反復し，休止後 2 週間目まで続けた。 T-, B-リンパ球数の算定はE-, EAC-ロゼットによった，HBs 抗原価の測定は RPHA 法, HBs 抗体価の測定は PHA 法によった。 in vitro での phytohemoagglutinin (PHA) に対する反応は ${ }^{3} \mathrm{H}$-thymidine取り込み率により，in vivo での反応は PHA $1 \mu \mathrm{g}$ を皮内注射し，24時間後に紅斑 の直径を測定して行なった，MIF の測定はモルモット 腹脉マクロファージを用い，間接法により，添加抗原と して immuno-adsorbent 法により得た精製 HBs 抗原を $100 \mu \mathrm{g} / \mathrm{ml}$ の濃度で用いた。

\section{成积}

1) $\mathbf{T}-, \mathbf{B}$ リンパ球数 : 開始前，総りンパ球，T-リン パ球は減少し，B-リンパ球は增加している例が多かっ た. 開始後，全体としては T-, B-リンパ球共に增加し， 約 6 週後以降は再び減少する傾向にあった。しかし当初 B-リンパ球が明らかに增加していた例では，開始後に減 少が見られ，その後再び増加した。

2）HBs抗原価 : 開始前, 抗原価は種々であったが， 全体としては約 6 週後まで上昇し，その後再び低下する 傾向にあった。しかし当初より抗原価の高かった 2 例で は，開始後に逆に低下が見られた。

3） HBs 抗体価：抗体陽性の 3 例の抗体価の動向は, $\mathrm{HBs}$ 抗原の動向とは背反的に，開始後に全例で上昇し た。

4) HBs 抗原による MIF 産生 : 開始前, 多くの例 で陽性であったが，次第に陽性例が減少し，その後再び 陽性化する傾向があった．再陽性化の時期は，HBs抗原 陽性例では，抗原価の再低下の時期に一致する例が多か った．HBs 抗体陽性例においても，MIF 陰性化が見ら れた。

5）兔疫グロブリン：開始前，各クラス共に全例で著 しく増加していたが，約 6 週後には多くは正常範用近く まで減少した。しかしこれも一過性であり，後半期には 再び増加した．終了時まで減少の傾向を維持しえたの は，HBs抗体陽性の 2 例のみであった。また経過中，殆 ど変化を示さないものる 1 例見られ，中等度の HBs 抗 原価す変化しなかった。
6）補体：開始前にCH 50が明らかに低下していたの は 1 例であり，この例では経過中，有意の上舁は見られ なかった．全体としては $\mathrm{CH}$ 50は次第に低下し， $\mathbf{C}_{3}, \mathrm{C}_{4}$ の蛋白量から見ても同様であった．CH 50の急速な低下 は，多くの例で HBs 抗原洒の再低下，免疫グロブリン の再増加の時期に合致した。

7）自己抗体：開始前に陽性であったのは抗核抗体 1 例，抗平滑筋抗体 1 例の計 2 症例であった。しかし開始 後の陽性例は，抗核抗体 5 例，抗平滑筋抗体 4 例の計 6 症例であった.かかる動向は HBs 抗体陽性例の抗体価 の動向に類似していた。

8） In vitro での PHA 反応：開始前, 大部分の例 で著しく低下していたが，約 6 週後には多くは正常範用 にまで正常化し，その後再びやや低下寸る傾向があっ た。順調に改善するもの，動播しながら改善するものが 見られたが，悪化の一途を辿るるのはなかった。

9) in vivo での PHA 反応：開始前には多くの例で 低下していた。しかし in vitroでの PHA 反応の動向之 は背反的に, 開始後, 急速に更に低下し, その後, 徐々 に改善する傾向にあった。これはステロイドの抗炎症作 用を反映し，その指標になりらるむのと考えられた。当 初より著しく低下していた 1 例では，開始後に徐々に改 善が見られた。

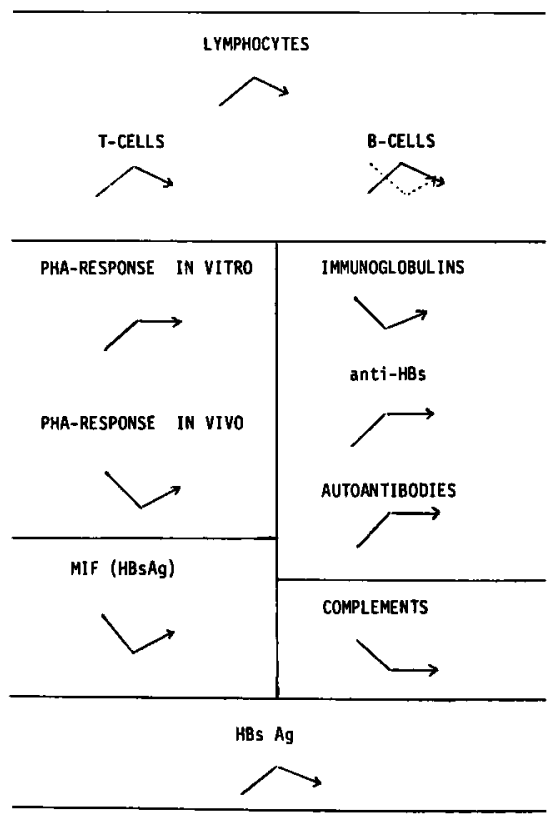

Fig. 2. Summary of results 


\section{まとめ}

以上の成績を総括してFig. 2 に示す。一部の例外的な パラメータを除けば，治療開始後，約 6 週間は carrier state の免疫学的状況に近つく効果を得たと言える。し かし，この効果は一過性であり，その後は当初の状態に 復㷌する傾向が見られた。このような成績は，本療法の 適応を，短期間の使用で目的を達成しらる場合，即ち壊 死シュープに限定すべきかの問題を提起するものと考兄 る.また HBs 抗原価が高く，比較的安定した症例に本 療法を適用した場合, 病像を悪化させる可能性のあるこ とを指摘したい。
HBs抗原陰性の 3 例については，今回はまだしも良好 な効果を得たが，結論には到らなかった。

索引用語 : 免疫抑制療法, persistent tolerant infection, carrier state

\section{文献}

1) 稲垣威彦注か: HBs 抗原 asymptomatic carrier の免疫学的研究. 肝臓, 16: 702 711, 1975,

2）稻垣威彦活か：B 型肝炎之細胞性免疫. 綜合臨 床. $24: 2365 \sim 2371,1975$.

3）稲垣威彦ほか；免疫学的に見た慢性肝疾患のス テロイド療法. 診断と治療. $65 ； 47 \sim 51 ， 1977$.

\section{ま と め}

市田文弘

河野氏は，肝に括けるグルココルチコイドの代謝に関 する問題を，天然型と合成クルココルチュイドとを比較 して基礎的に解説した。 また，矢野氏はステロイドホル モンの作用機序に関する最近の知見についてのべ，グル ココルチコイドは炎症の全過程に影響を与え，とくにア レルギー炎症においては，第 3 型（アルサス型）および 第 4 型 (ツベルクリン型) に対する影響が顯著である. しかしリンパ組織のステロイトに対する感受性は敇属に よって異なり，ヒトでは resistant であり，同じ種属で す T-cell と B-cell とでは違いそれぞれの cell line ですその成熟段階によって，その感受性が違っているよ らである。

山本氏，太田氏，稲垣氏は臨床例を対象として，プレ ドニソロンの慢性肝疾患に対する有効性について，主と して細胞性免度，HBs抗原一抗体系への影辢，および肝 の組織病変の推移から検討を加えた成績をそれぞれ報告 した。

このパネルに括ける討論から，慢性肝疾患のうちで， ステロイド療法のもっともよい適応になるのはルポイド 肝炎以外に，要小葉性塤死をくり返しながら，比較的早
く肝硬変へ進展すると考えられる慢性肝炎（活動性）で あり，その際の HBs 抗原一抗体系の動きからみると， グルココルチェイドはこの抗原抗体系には大きな影響を 与えているとは思われないので, HBs 抗原持続陽性の 慢性肝疾患に使用してもよいといらことで一致した。 たこのステロイド療法では，免疫㧕制効果よりも抗炎 症作用の効果を期待して，プレドニソロンの少量（20 $\mathrm{mg} /$ 日)をなるべく長期にわたって使用すべきであると 結論された。しかも副作用の出現を考虑して，慢性肝炎 （活動性）の経過中にみられるシュープに際してはプレ ドニソロンの連日投与, シューブの消失後は隔日投与を 行う万法が新しく提案された。

またステロイド療法の副作用として，周知のように満 月様顔ば5，糖尿病，胃十二指腸謴瘍，骨の变化などが あげられ，ステロイドの投与が長期にわたる際には，と くに留意されなければならない，その予防対策として， プレドニソロンのよらな short acting steroidを隔日 1 回 投与法が副作用の発現を少なくする最善の方法であるの で，慢性肝疾患のステロイド療法にこの方法が導入され るべきであるといら提案がなされた。 